\title{
7 LATED AND TRAUMATIZED SELF(VES) IN AUTOBIOGRAPHIES FROM THE ROMANIAN FRONT
}

\section{Costel Coroban}

“Ovidius" University of Constanța, E-mail: coroban_costel@yahoo.com

\section{Acknowledgements}

This paper has been presented at the Ninth Annual International Conference on Baltic and Nordic Studies in Romania: 100 Years since Modern Independence and Unification in Baltic Sea Region and East-Central Europe held in Târgoviște, Romania, during November 15-16, 2018.

\begin{abstract}
:
In the article Elated and Traumatized Self(ves), the focus has been on the horrific images witnessed by which the nurses changed their initially optimistic discourse on war. In his study on the memory of the Great War, Paul Fussell identifies recurring elements such as miracles and perils, rituals, magic numbers, a magical, otherworldly landscape, social arrangements that culminate in pompous ceremonies, the constant training of the protagonist to prove himself against danger, and the fact that the protagonist and his allies often constitute a group of solidarity or "community of the elect" (Fussell 1975, 135). Looking for these elements in the nurses' narratives, I have identified them in their attitude towards the war before they reached the front. The situations of shock they faced caused them to abandon the "heroic pageantry of war" (in Claire M. Tylee's terms) and to replace it with a language of trauma that desisted in intensity after witnessing bombardments and after patients with horrible injuries became ordinary events in their lives.
\end{abstract}

\section{Rezumat:}

In articolul Sinele între euforie și traumă accentul este pus pe imaginile oribile la care au asistat femeile scoțiene și care le-au determinat să ișsi schimbe discursul inițial optimist cu privire la război. In studiul său despre memoria Marelui Război, Paul Fussell identifica elemente recurente, cum ar fi: miracolele și pericolele de la tot pasul, ritualismul, folosirea numerele magice, descrierea peisajului ireal, desprins din altă lume, existența unor evenimente sociale care culminează prin ceremonii pompoase, pregătirea constantă a protagonistului pentru a se confrunta cu pericolul și faptul că protagonistul și aliații săi constituie adesea un grup de solidaritate sau o "comunitate a aleșilor" (Fussell 1975, 135). Analizând narațiunile din jurnalele asistentelor 
medicale, am identificat aceste elemente în atitudinea lor faț̆ de război, înainte de a ajunge pe front. Situațiile de șoc cu care s-au confruntat le-au determinat să renunțe la "spectacolul eroic al războiului" (în termenii lui Claire M. Tylee) în discurs și să îl inlocuiască cu un limbaj specific traumei care s-a domolit treptat după ce au fost martore la bombardamente și după ce tratarea pacienților cu leziuni oribile au devenit evenimente obișnuite din viețile lor.

Keywords: Scottish Women's Hospitals, Romania, World War I, Dobruja front, women and war

The hypothesis is that self-examination in the Scottish women's diaries was prompted by the tragedy and trauma of the violent conflict ravaging the country, and that this self-analysis resulted in the nurses changing their attitude towards the war, which they no longer saw as glorious or as an "adventure", but were able to perceive in its full horror. The failure of the Romanians and Russians on the Dobruja front - considered of secondary significance - disillusioned not only the Scottish nurses, but the entire Romanian army and the already sceptical representatives of the Russian imperial army. It is certain that the Central Powers assigned greater importance to this section of the Eastern Front. The three Romanian divisions defending Dobruja (stationed at Turtucaia, Silistra and Bazargic) plus the two Russian divisions were facing the 3rd Bulgarian Army supplied with modern German equipment and technical personnel.

Concerning the general image of the war for those at home and those on the front, Victoria Stewart observes that "Abstract ideas about war took prevalence over actual knowledge, and the clash between ideals and practicality was a difficult one to reconcile"1. In the seminal study No Man's Land: Combat and Identity in World War 1, Eric J. Leed marks the difference between "the military way" and "militarism" 2 . The former notion refers to a discourse about war in which practical aspects are brought to the foreground, while the latter means a "system of images, symbols, and rituals designed to express the character of the 'warrior' and the character of the

\footnotetext{
1 Victoria Stewart, Women's Autobiography, War and Trauma (New York: Macmillan, 2003), 36.

2 Eric J. Leed, No Man's Land: Combat and Identity in World War 1 (Cambridge: Cambridge University Press, 1979), 56-57.
} 
community in which he is at home" 3 . As we shall see, the accounts of the Scottish nurses on the Eastern Front are a mix of the two, with 'the military way' probably holding the upper ground. The nurses held the view that war is 'ennobling', especially winning the war and this is reflected in their description of the military personnel they encountered and their enthusiasm when meeting the British soldiers in the Armoured Car Division. Yet, they were more concerned with the more practical aspects relating to the army and to their own activity. To them, the generals are those who decide where the hospitals shall function, and quite often, when they should quickly pack everything and retreat in case of enemy advance.

The nurses who came to the front found themselves in an unprecedented situation. Laurie Kaplen shows that these ladies belonged to "The new generation of young women, some of whom had never seen a naked man, much less a suppurating wound or mangled body..."4. Many questions arise: how would these women cope with the new setting they found themselves in? What did the nurses make of this male universe, the war theatre - coupled with the operation theatre - they were suddenly admitted to? To what extent did they allow their prejudice of military affairs and war to take over in their description of the soldiers they met? Did this cultural encounter change their perspectives of themselves? Such queries will mark the present research. To give a short example, Ethel Moir, one of the orderlies and, as previously seen, a writer inclined towards highly romanticized descriptions, made the following note after experiencing military instruction on the ship that transported the SWH to Europe in 1916: "I'm writing this 'standing at attention' at my bunk, waiting for 'cabin inspection'. We have to undergo such a lot of nonsense in the way of drills, saluting, etc. - talk about soldiers!"5. It is a clear example of the shock we might expect of those unacquainted with military discipline, and whose military inexperience allowed a self-ironical attitude. To Ethel Moir, the

\footnotetext{
${ }^{3}$ Leed 1979, 57 quoted in Stewart 2003, 36.

${ }^{4}$ Laurie Kaplan, "When the War Was Over: The Return of the War Nurse." Writings of Persuasion and Dissonance in the Great War, David Owen \& Cristina Pividori eds. (Leiden: Brill, 2016), 69.

${ }^{5}$ Audrey Fawcett Cahill (ed.). Between the Lines: Letters and Diaries from Elsie Inglis's Russian Unit (Edinburgh, Cambridge: The Pentland Press, 1999), 18.
} 
condition of the soldier is equated to that of an individual whose freedom and identity becomes lost in "drills, saluting, etc".

Vera Brittain noted in her famous war diary, Testament of Youth, that the nurses longed to be heroic, but the administration only permitted them a secondary role in war and concluded: "Women get all the dreariness of war, and none of its exhilaration" 6 . The assumption that, for men, war is 'exhilarating' imparts the traditionalistic/imperialistic perception of war propagated by the government(s). One of the most important pieces of literature when discussing the way women saw their relationship with the men on the front is Claire M. Tylee's The Great War and Women's Consciousness. Images of Militarism and Womanhood in Women's Writings 19141964, which has become one of the fundamental works on women's war writings. While Fussell, whom we have mentioned in previous studies and books, was concerned with what men wrote during the Great War, Tylee did the same but focused on women. She highlights how nurses or other women present on the front fail to see behind their government's propaganda and were 'easy victims' of it, not because of the legislation that prohibited any anti-war texts ${ }^{7}$, but because they lacked the intellectual flexibility required to adopt a different perspective on war, even after dealing with the horrible suffering of their patients. Christine E. Hallett calls this "the mental straitjacket of their upbringing within a patriarchal and imperialistic society"8.

Claire M. Tylee uses the phrase "the heroic pageantry of war" to refer to the spirit of adventure which captivated many young men and women who had no idea about the horror and trauma they would witness and suffer - on the eve of the First World War. The same scholar shows that women had trouble in finding a language that was adequate to describe their experiences during the war because "The idea of war was intimately connected with many other values of Western culture. To challenge its heroic

\footnotetext{
6 Vera Brittain, Testament of Youth: An Autobiographical Study of the Years 1900-1925 (London: Virago, 1978), 104.

7 Defence of the Realm Act, 1914.

8 Christine Hallett, Veiled Warriors: Allied Nurses of the First World War (Oxford: Oxford University Press, 2014), 4.
} 
image was to undermine ideas fundamental to their world and to their conception of history" 9 .

It was not surprising that women, who up to that moment lived relatively domestic lives, would see their sojourn on the Eastern Front as an extraordinary adventure. This was coupled with the government's propaganda that aimed to persuade as many young men as possible to join the front by turning war into a righteous crusade against barbarous enemies. As a result, many of the nurses took up this rhetoric in their journals and consequently expressed their eagerness to become part of the glorified war effort. Katherine Hodges, one of the ambulance drivers, almost feels the need to justify her presence at the front, in the world of men. While on the ship that was transporting them eastwards, she recounts her joining the Scottish Women's Hospitals in the fashion of an unexpected escapade. Hodges' adhesion to the ambulance unit of the SWH as a driver is clearly outside the boundaries set by the British government that regulated the "home front". The language used in the diary expresses her astonishment at succeeding in this feat in spite of hostile odds: the driver accidentally found out about the possibility of work at the front, while performing a chore in the garage. As she had been trying to find work at the front for a long time, Hodges wasted no time. She took a cab to the SWH headquarters, where she was straightaway welcomed to join the "round table" of the Transport Unit by its leader, the "Honourable" Evelina Haverfield (an honorific form of address reserved at the beginning of the $20^{\text {th }}$ century to venerable men). This fragment is one of the very few in which Mrs Haverfield is depicted in a positive light. Most of the drivers who wrote accounts of her at the front found her very difficult to deal with, which probably led her to suffer a nervous breakdown and to her returning home earlier. Katherine Hodges's enthusiasm to join the front and her being "delighted" at the prospect does not uniquely mark her excitement on that specific day. Her confession is a common description of how the rest of the drivers and the nurses saw themselves in relation to their roles within the war system and reflects the view of the general public on such matters ${ }^{10}$.

\footnotetext{
${ }^{9}$ Claire M. Tylee The Great War and Women's Consciousness: Images of Militarism and Womanhood in Women's Writings, 1914-1964 (London: Macmillan, 1990), 20.

10 Cahill 1999, 15-16.
} 
In Memoirs of First World War Nurses: Making Meaning of Traumatic Experiences, Maxine Alterio shows that, at the beginning of the Great War there were few who foresaw the horrors and destruction caused by war and who actually envisaged the series of actions that had led to its outbreak. There were many who thought that military victory would contribute to more equality and prosperity, and who were blinded by political propaganda, by the general spirit of optimism at the time and by the comfort brought by recent industrial developments ${ }^{11}$.

While on her way to Romania in September 1916, Elinor Rendel was writing home the following in a letter, anticipating her "adventure":

It reminds me in some ways of the WS and WCC and our camp life at Studland. So many of the women here have belonged to semi-military organisations such as the Women's Reserve Corps, etc., in which they do a lot of saluting, that the military spirit has crept in - much to the annoyance of the sisters, who have already begun to rebel [...]

Some of the criticism is true, I think. Some of our leaders have been bitten with the military craze and they love saluting, giving orders, etc. without having grappled with the essentials. They rather like making us salute them for example without dreaming of returning the salute. However I think it's all been rather a game to pass the time and make us forget submarines. ${ }^{12}$

The famous World War 1 poster that reads "Are YOU in this?" displays, in a chain of work, what each social category should be doing to support the soldiers at the front: men and women on the "home front" are depicted working in the production of ammunition, while on the real front soldiers are first assisted by boy scouts who are passing them bullets, and only then by women nurses (sic!), who are described as "dispensing care rather than treatment"13, and certainly not driving ambulance cars or using

11 Maxine G. Alterio, Memoirs of First World War Nurses: Making Meaning of Traumatic Experiences. PhD Thesis (Wellington: Victoria University of Wellington, 2013). on-line: http:/ / researcharchive.vuw.ac.nz/xmlui/bitstream/handle/10063/2798/thesis.pdf?sequen ce $=6,8$.

12 In Cahill 1999, 21.

${ }^{13}$ Heather Kate MacNamara, "Are not All Angels Ministering Spirits": Representations of British Military Nurses and the First World War. Master of Arts thesis manuscript. Kingston: National Library 
X-ray devices. For the government's and the military authorities' spatial understanding of the front, the nurse is situated behind the Boy Scout, therefore closer to the "home front", so adult women were considered less fit for military experience than very young boys even. A moment of similar revelation was the decoration of the nurses in March 1917 in Bessarabia, which was recorded by Margaret Fawcett. First, the nurses were decorated after the wounded soldiers had been given their medals, the same soldiers that they regarded with pity and who were the nameless victims of the war. Second, even the nurse who described the moment admitted that they did not expect to receive the same decorations as the militaries did. This example shows how challenging it was for women to "write themselves back"14 into the memory of the Great War. Worthiness on the front as well as access to the vault of war memory were awarded by proximity to trauma.

Elinor Rendel further marks a clear difference between herself and the other women who seem to have had previous semi-military experience. Rendel expresses a similar dislike for the masculine code of military saluting and the rest of the war panoplies that displace the nurses into the masculine universe of war. Mary Milne, the cook of the SWH unit, wrote about another step in the masculinization of the female body while the women were on the ship on their journey to the front: their hair had to be cut by the ship's barber ${ }^{15}$. This physical change complements the behavioural transformations required to enter the masculinized world of the front. Mary Milne is obviously not thrilled with the abolition of her womanliness, but she accepts it as an expected requirement to join the front troops.

Passages like the two above suggest that the medical women experienced certain difficulties in adopting militarism and expressed their limited revolt to have to take up a masculine attitude to war in the diaries they wrote. Dr. Elsie Inglis, the leader of the Scottish nurses remarked with certain satisfaction that, on one occasion, one of the women in the Ambulance unit had gone to the engine room of the ship they were sailing in with a greaser and when she returned covered in grease, one of the officers

https://www.collectionscanada.gc.ca/obj/s4/f2/dsk2/tape17/PQDD_0002/MQ28228.pdf, 81.

14 Hélène Cixous, "The Laugh of the Medusa." Signs 1, no. 4 (1976): 875-893.

15 Cahill 1999, 22. 
stopped her and said 'Now where are you going to, my lad?'"16. On a different occasion, Dr. Elsie Inglis disciplines the ambulance drivers for acting too much like men, as Ysabel Birkbeck recounts on November 30, 1916: "Dr Inglis harangued the Transport after breakfast. The first part was against the nasty habits of the Transport; somebody's been swearing, it seems, as if there's not plenty to swear about"17. Besides the comical aspect, the Commanding Officer's observation is in line with the organisation's intention to destroy the barrier between genders and prove that women could be just as useful as men on the front ${ }^{18}$, but the nurses and ambulance drivers felt on occasions great psychological pressure at the difficulty of fitting to the role of men while having to behave like ladies.

It seems that the status of the Ambulance unit was central in establishing the collective identity of the SWH organization. The position of nurse fitted perfectly into the traditional roles reserved for women, but not the same could be said for the position of driver. At the beginning of the $20^{\text {th }}$ century, being a chauffeur was an entirely new occupation in the world of men as well, therefore the reticence of accepting women in this role that belonged to the world of men may be easily explained. Dr. Elsie Inglis's ideals were more important than what she saw as unnecessary caution. The ambulance drivers were an important part of the Scottish nurses' identity and giving it up was comparable to her to giving up the hospitals.

Before embarking on the ship that would take them to the East, Nurse Lilias Grant described the Ambulance or Transport unit of their hospital in very kind words, looking quite envious of the fascination they exercised on the public while marching, as quaint remarks came from the public, such as "Now I shouldn't mind joining that lot", or "They are not going into danger at all"19. The disjunction between the way one of the nurses saw the Ambulance unit and the way in which the prejudiced public reacted opens the topic of the masculinized female body. In her Masculinity and the Wounds of the First World War: A Centenary Reflection, Ana Carden-Coyne asserts that "masculinity underpinned imperialism and militarism, fundamentally

\footnotetext{
16 Cahill 1999, 21.

17 Cahill 1999, 136.

18 Jane McDermid, "What's in a name?: The Scottish Women's Hospitals in the First World War." Minerva Journal of Women and War 1, no. 1 (2007): 102-114.

19 Cahill 1999, 16.
} 
shaping the experience of modern war as social, embodied and psychological experiences" 20 . The women desired to be seen as men in order to be able to claim the same rights, yet the Scottish nurses did not accept this masculinization without protest. The public comment, "They are not going into danger at all" excludes women from the "honour" of becoming a victim of the war, which is part of the world of men. It is also possible that Lilias Grant may not have been entirely honest in her journal and actually expressed her own doubt at the thought that the ambulance drivers - the "stars" of the SWH unit - would be more exposed to danger than the usual nurses or orderlies.

In a different account, this time from the early days of the Scottish nurses' hospital in Medgidia, Nurse Yvonne Fitzroy wrote down what an honour it was to dine with the drivers, whom she called "the ultra-exclusive Transport" 21. The account is revelatory in establishing the identity of the SWH unit because Fitzroy marks a clear difference between her status as a nurse and the esteemed positions of the ambulance drivers and commanding officer. Even though the presence of the nurses was meant to break the social order of the time, the women were subjected to authority within their organization almost in the same way as in the society, so there was little encouragement for the usual nurse to adopt a different point of view on the war that was raging and to dispel its "heroic pageantry". Almost a week before arrival at the front in Dobruja in 1916 ambulance driver Katherine Hodge expressed her eagerness by remarking they were "not within fifty miles of the fun!"22.

Maintaining the same high spirits, Ethel Moir was writing in November 1916, after the harrowing experience of the retreat from Dobruja, that she would not have missed it for anything in the world ${ }^{23}$ (Cahill 104). The image Moir is describing herself in is that of an adventurous hero, and it is surprising that the other nurses were so marked by the horrors of retreat they had just been through. Some wrote in their journals that they would

\footnotetext{
20 Ana Carden-Coyne, "Masculinity and the Wounds of the First World War: A Centenary Reflection." Revue Française de Civilisation Britannique, XX, no. 1 (2015), on-line: http://journals.openedition.org/rfcb/305, 2.

${ }_{21}$ In Cahill 1999, 28.

22 In Cahill 1999, 33.

23 Cahill 1999, 104.
} 
never forget the faces of the refugees. Ethel Moir maintains the Romantic image of the "young, wide eyed, innocent nurses and domesticated representations of the nursing space" 24 by ascribing to an image of herself as a fearless adventurer. Elinor Rendel similarly remarks how overjoyed she was to be part of the war experience: "I am now having the time of my life and enjoying myself more than I have for years. It is really great fun here" 25 . It is interesting how merely doing her job means, to the nurse, having great fun. It is also obvious that the nurse was both adventurous and passionate in doing her job.

Ambulance driver Katherine Hodges continued to express anticipation as well as wonder as the nurses were getting close to the front. She appears very excited, even "jolly glad" at the thought of getting into "the thick of fighting", at the same time expecting to face the fear successfully ${ }^{26}$. This defies traditional gender roles in which women are expected to adopt a passive attitude to war, and this aspect leads to what has been called "gender blurring". Such high spirits were maintained in the descriptions of Lois Grant after their retreat from Ciocârlia de Jos in October 1916. She confesses that she believed she and her friend, Ethel Moir, had been in the care of a greater power "than any earthly one" 27 . She made her statement in spite of the poor state of the car in which they were making their escape, which they expected to come to bits at any moment, and in spite of the burning line on the horizon. The bravado of Grant is inspiring and worthy of being used as an example to teach others how to behave in similar situations. The Christian ideology of the two nurses - who express faith in being protected by Providence - is included in the "Christian mythology of chivalry" regarding the war, developed by Claire M. Tylee in her book, where she argues that such descriptions of the nurses reinforce traditional nationalist discourse about war ${ }^{28}$ because they do not challenge the legitimacy of the war or those who started it and caused so much destruction and suffering. This

\footnotetext{
24 MacNamara 1998, 71.

25 Cahill 1999, 55.

26 Cahill 1999, 32.

27 In Cahill 1999, 89.

28 Tylee 1990, 26.
} 
proposition can be complemented by Santanu Das's theory of the "silent witnessing" attribute to women in the Great War ${ }^{29}$.

Elsie Bowerman displays similar unbridled enthusiasm for the adventure the nurses were on in Romania, almost mirroring the religious fervour of a crusading army:

“...There's much to tell you about the people, much too long to write, but they are a ripping lot. It is so nice to get with a set of people who are all keen, all see the funny side of things, all prepared to face anything" ${ }^{\prime \prime}$.

In spite of this eagerness, the nurses hesitated to situate themselves in the male-only universe of war, as their lamentation against having to observe military regulations or to having to have their hair cut. In the excerpts above it is clear how eager the nurses were to travel to the front and begin their work, refraining from directly glorifying war, but showing the kind of naïve enthusiasm historians usually criticize as regards those who had little idea about the destruction the war would bring. By the end of September 1916, which was the time when the Scottish nurses arrived at the front in Dobruja, the position of the Allies on the Dobruja front had been seriously weakened by the defeat at Turtucaia following the battle between 2 and 6 September 1916. Turtucaia was defended by approximately 39,000 Romanian troops (of which 34,000 became casualties while the rest were able to flee across the Danube to Silistra). The Russian troops in Dobruja were concentrated in a more eastern position at Cobadin. In the meantime, on 3 September 1916 Brigade General Nicolae Arghirescu, the commander of the 19th Infantry Division, had decided on the evacuation of Bazargic and began retreating north of the city ${ }^{31}$. The lack of communication between the Russian and Romanian commands, the halting of the Salonika offensive by General Sarrail ${ }^{32}$, the reduced sized and strength of the Russian divisions sent to help

\footnotetext{
29 Santanu Das, Touch and Intimacy in First World War Literature (Cambridge: Cambridge University Press, 2006).

30 In Cahill 1999, 20.

31 Gheorghe Platon, Istoria Românilor. Vol. VII. Tom II. De la Independență la Marea Unire (18781918) [The History of the Romanians. Vol. VII. Tome II. From Independence to the Great Unification (1878-1918)] (Bucureşti: Editura Enciclopedică, 2003), 423.

32 General Maurice Sarrail was a French general who commanded the multinational Allied force during the Salonika campaign (December 1915-December 1917), intending, but failing to prevent the Central Powers' conquest of Serbia, Wallachia and Dobruja.
} 
Romania, coupled with the intensification of the offensive of the Central Powers' forces under Marshal von Mackensen on the Rasova - Cobadin Topraisar - Tuzla line (repelled but with heavy casualties suffered by the defenders), were the factors that contributed towards the difficult situation found by the Scottish nurses on their arrival in Romania ${ }^{33}$.

33 Platon 2003, 424. 


\section{References:}

Alterio, Maxine G. Memoirs of First World War Nurses: Making Meaning of Traumatic Experiences. PhD Thesis (Wellington: Victoria University of Wellington, 2013).

on-line: http:/ / researcharchive.vuw.ac.nz/xmlui/bitstream/handle/10063/2798/t hesis.pdf?sequence $=6$

Brittain, Vera. Testament of Youth: An Autobiographical Study of the Years 1900-1925 (London: Virago, 1978)

Cahill, Audrey Fawcett (ed.). Between the Lines: Letters and Diaries from Elsie Inglis's Russian Unit (Edinburgh, Cambridge: The Pentland Press, 1999)

Carden-Coyne, Ana. "Masculinity and the Wounds of the First World War: A Centenary Reflection." Revue Française de Civilisation Britannique, XX, no. 1 (2015), on-line: http:/ /journals.openedition.org/rfcb/305

Cixous, Hélène. "The Laugh of the Medusa." Signs 1, no. 4 (1976): 875893

Das, Santanu. Touch and Intimacy in First World War Literature (Cambridge: Cambridge University Press, 2006)

Hallett, Christine. Veiled Warriors: Allied Nurses of the First World War (Oxford: Oxford University Press, 2014)

Kaplan, Laurie. "When the War Was Over: The Return of the War Nurse." Writings of Persuasion and Dissonance in the Great War, David Owen \& Cristina Pividori eds. (Leiden: Brill, 2016) 65-80

Leed, Eric J. No Man's Land: Combat and Identity in World War 1 (Cambridge: Cambridge University Press, 1979)

MacNamara, Heather Kate. "Are not All Angels Ministering Spirits": Representations of British Military Nurses and the First World War. Master of Arts thesis manuscript. Kingston: National Library of Canada, 1998, on-line: https://www.collectionscanada.gc.ca/obj/s4/f2/dsk2/tape17/PQDD_000 2/MQ28228.pdf

McDermid, Jane. "What's in a name?: The Scottish Women's Hospitals in the First World War." Minerva Journal of Women and War 1, no. 1 (2007): 102-114

Stewart, Victoria. Women's Autobiography, War and Trauma (New York: Macmillan, 2003) 
84 | Revista Română de Studii Baltice şi Nordice/The Romanian Journal for Baltic and Nordic Studies 10 (1)

Tylee, Claire M. The Great War and Women's Consciousness: Images of Militarism and Womanhood in Women's Writings, 1914-1964 (London: Macmillan, 1990) 